\title{
Studies of Very Severe Short Stature with Severe GH Deficiency: From the Data Registered with the Foundation for Growth Science
} \author{
The Foundation for Growth Science, Japan \\ ${ }^{1}$ Hanew Endocrine Clinic \\ ${ }^{2}$ Kanagawa Children's Medical Center \\ ${ }^{3}$ Toranomon Hospital \\ ${ }^{4}$ Asahikawa Medical College \\ ${ }^{5}$ National Research Institute for Child Health and Development \\ ${ }^{6}$ Igarashi Children's Clinic \\ ${ }^{7}$ Kyoto National Hospital \\ ${ }^{8}$ Okayama University \\ ${ }^{9}$ Hyogo College of Medicine \\ ${ }^{10}$ Nippon Medical College \\ ${ }^{11}$ Hiroshima Red Cross Hospital \& Atomic Bomb Hospital \\ ${ }^{12}$ Tokyo Metropolitan Kiyose Children's Hospital \\ ${ }^{13}$ Tokyo Women's Medical University \\ ${ }^{14}$ Hirano Children's Clinic \\ ${ }^{15}$ Osaka City General Hospital
}

KUNIHIKO HANEW ${ }^{1}$, KATSUHIKO TACHIBANA ${ }^{2}$, SUSUMU YOKOYA ${ }^{3}$, KENJI FUJIEDA ${ }^{4}$, TOSHIAKI TANAKA ${ }^{5}$, YUTAKA IGARASHI ${ }^{6}$, AKIRA SHIMATSU ${ }^{7}$, HIROYUKI TANAKA ${ }^{8}$, TAKAKUNI TANIZAWA ${ }^{9}$, AKIRA TERAMOTO ${ }^{10}$, YOSHIKAZU NISHI ${ }^{11}$, YUKIHIRO HASEGAWA ${ }^{12}$, NAOMI HIZUKA ${ }^{13}$, TAKEKI HIRANO ${ }^{14}$ AND KEINOSUKE FUJITA ${ }^{15}$; GH Treatment Study Committee,

\begin{abstract}
The ratio, clinical characteristics, and therapeutic efficacy of hGH treatment in patients with severe short stature (HtSDS below -4SD) with severe GHD (all peak GH values to provocation tests: below $2 \mu \mathrm{g} / \mathrm{L}$ ) were studied. From March 1986 to January 1998, 23,110 patients with idiopathic GH deficiency (IGHD) were registered with the Foundation for Growth Science, Japan. These subjects were divided into 5 groups as follows: Group 1 (G1), all subjects; Group 2 (G2), at least one $\mathrm{GH}$ peak to provocative test $\geq 5 \mu \mathrm{g} / \mathrm{L}$; Group 3 (G3), $2 \mu \mathrm{g} / \mathrm{L} \leq \mathrm{GH}$ peak $<5 \mu \mathrm{g} / \mathrm{L}$; Group 4 (G4), all GH peaks $<2 \mu \mathrm{g} / \mathrm{L}$ and HtSDS $>-4$; Group 5 (G5), all GH peaks $<2 \mu \mathrm{g} / \mathrm{L}$ and HtSDS $\leq-4$. The ratio of G5 was 139 patients $(0.6 \%)$ out of 23,110 patients with IGHD. In G5, there were no significant differences in birth weight, birth length, gestational age and parental height between G2, G3 and G4. However, asphyxia at delivery was more frequent in G5 and G4 than G2 and G3. Chronological age (CA), bone age (BA) and BA/CA ratio at registration were significantly lower in G5 than G2, G3 and G4. Further, the IGF-I SD score in G5 was significantly lower than those in G2 and G3. After hGH treatment, the final height and final height SDS in G5 remained the lowest, while the $\Delta$ HtSDS value in G5 was the greatest among G2 to G5 groups. In conclusion, the ratio of severe short stature with severe GH deficiency (G5) is only $0.6 \%$ of all IGHD cases. Growth failure in G5 seems to occur after birth, and its etiology in G5 seems to be different from that of patients with other forms of IGHD. Early diagnosis and hGH treatment are needed to attain better final height.
\end{abstract}

Key words: Severe short stature, Severe GHD, Idiopathic GHD

(Endocrine Journal 52: 37-43, 2005)

RECENTLY, many growth disorders caused by genetic abnormalities, such as GH-1 gene, its transcrip-

Received: February 4, 2004

Accepted: September 7, 2004

Correspondence to: Dr. Kunihiko HANEW, Hanew Endocrine Clinic, 2-5 Hasekuracho, Aobaku, Sendai 980-0824, Japan tion factors (Pit-1, PROP-1, HESX-1), GHRH-receptor gene, GH receptor gene and IGF-I receptor gene have been reported [1-3]. These cases, except for patients with gene mutations of GH receptor or IGF-I receptor, usually show severe short stature (height SD score below -4 to -4.5 ) together with severe GH deficiency (peak GH value below $4 \mu \mathrm{g} / \mathrm{L}$ in conventional provo- 
cation tests) [4].

Short stature associated with GH deficiency is reported to be between 1 in 4,000 and 1 in 10,000 of the population in several studies [5-8]. However, the exact incidence of severe short stature with severe GH deficiency (GHD) among total short stature patients (HtSDS below -2), and the proportion of GH-related gene abnormalities in severe short stature with severe GHD have yet to be clarified. In the present study, we examined the ratio of patients with severe short stature and severe GHD in total idiopathic GHD (IGHD), and studied the clinical characteristics and therapeutic efficacy of hGH in these patients.

\section{Subjects and Methods}

Patients with IGHD who were approved by the Foundation for Growth Science (FGS), Japan from March, 1986 to January, 1998, to receive hGH treatment, were studied. These patients were non-organic and received no gonadal suppression therapy.

IGHD was diagnosed according to the following criteria: (1) age matched height SDS (HtSDS) was below -2 or growth rate/year was below $-1.5 \mathrm{SD}$ over 2 years, and (2) poor GH responses (peak GH value to provocation test was below $10 \mu \mathrm{g} / \mathrm{L}$ ) to two provocative stimuli; or the poor GH response to at least one stimulus and significantly low IGF-I value; or (3) low mean nocturnal GH value (below $3 \mu \mathrm{g} / \mathrm{L}$ ) for $3 \mathrm{hr}$ samplings at 20 min intervals together with low IGF-I and low urinary GH values despite normal GH responses to exogenous stimuli (so-called GH neurosecretory dysfunction). After registration with the Foundation for Growth Science (FGS), these patients were treated with recombinant human GH with the doses of $0.5 \mathrm{IU}=$ $0.17 \mathrm{mg} / \mathrm{kg} /$ week mainly 6 to 7 times a week.

These subjects were arbitrarily divided into 5 groups as follows: Group 1 (G1), all subjects; Group2 (G2), at least one GH peak to provocative test $\geq 5 \mu \mathrm{g} / \mathrm{L}$; Group 3 (G3), $2 \mu \mathrm{g} / \mathrm{L} \leq \mathrm{GH}$ peak $<5 \mu \mathrm{g} / \mathrm{L}$, Group 4 (G4); all GH peaks $<2 \mu \mathrm{g} / \mathrm{L}$ and HtSDS $>-4$ and; Group 5 (G5), all $\mathrm{GH}$ peaks $<2 \mu \mathrm{g} / \mathrm{L}$ and $\mathrm{HtSDS} \leq-4$. In this category, G1 is not simply the sum of G2, G3, G4 and G5, since one case which performed only one provocative test and whose peak GH value was below $5 \mu \mathrm{g} / \mathrm{L}$, or one case whose one peak GH value was below $2 \mu \mathrm{g} / \mathrm{L}$ while the other value was more than 2 and below 5 , were included in G1 but excluded from the other groups.
These five groups were analyzed based on the following parameters: (1) the number of each group at registration to FGS, (2) birth weight, (3) birth length, (4) gestational age, (5) incidence of asphyxia at delivery, (6) chronological age (CA) and (7) bone age (BA) at registration, (8) BA/CA ratio, (9) height at start of hGH treatment, (10) Height SDS (HtSDS) at start of hGH treatment, (11) SD score of serum IGF-I value (measured by RIA using extraction method) calculated from values of age-matched controls [9] at start of hGH treatment, (12) father's height, (13) mother's height, (14) final height (when growth rate fell below $2 \mathrm{~cm} / \mathrm{yr}$ ), (15) final height SDS, (16) $\Delta \mathrm{HtSDS}$ (final HtSDSpretreatment HtSDS).

Data are expressed as mean \pm S.E.M. and statistical analysis was conducted using Student's non-paired t-test or chi-square test for the comparison of the two parameters.

\section{Results}

\section{1) Number of each group of idiopathic GH deficiency}

As shown in Table 1, total number of patients (G1) in this study was 23,110 . Among them, the majority of patients $(89.1 \%)$ were G2. So-called classical severe GHD (all GH peaks to provocation tests less than $5 \mu \mathrm{g}$ / L) was $10.5 \%$ (2428 cases) of the total, and severe short stature with severe GHD (G5) was only $0.6 \%$ (139 cases).

2) Birth weight, birth length, gestational age and asphyxia at delivery in the 5 groups

In all groups, birth weight (G1: boy, $2913.3 \pm 4.0 \mathrm{~g}$, $\mathrm{n}=15,487$; girl $2840.1 \pm 5.7 \mathrm{~g}, \mathrm{n}=7,128$; G5: boy, $2978.4 \pm 61.6 \mathrm{~g}, \mathrm{n}=81$; girl, $2939.3 \pm 94.9 \mathrm{~g}, \mathrm{n}=54$ ) (Table 2a), birth length (G1: boy, $48.1 \pm 0.04 \mathrm{~cm}$, $\mathrm{n}=4,431$; girl, $47.6 \pm 0.07 \mathrm{~cm}, \mathrm{n}=2,163$; G5: boy,

Table 1. Numbers of each group of idiopathic GH deficiency

\begin{tabular}{rrrrr}
\hline & boy & \multicolumn{1}{c}{ girl } & total & rate (\%) \\
\hline G1 & 15,824 & 7,286 & 23,110 & 100 \\
G2 & 14,033 & 6,568 & 20,601 & 89.1 \\
G3 & 1,341 & 550 & 1,891 & 8.2 \\
G4 & 306 & 92 & 398 & 1.7 \\
G5 & 83 & 56 & 139 & 0.6 \\
\hline
\end{tabular}


$46.5 \pm 2.56 \mathrm{~cm}, \mathrm{n}=5 ;$ girl, $47.3 \pm 0.87 \mathrm{~cm}, \mathrm{n}=6$ ) (Table 2b) and gestational age [G1 (total), $39.1 \pm 0.01$ weeks, $\mathrm{n}=22,110$; G5 (total), $38.9 \pm 0.24$ weeks, $\mathrm{n}=$ 129] (Table 2c) were within normal ranges. The birth weight of patients in G5 was slightly greater than G2, $\mathrm{G} 3$ and $\mathrm{G} 4(\mathrm{P}=\mathrm{NS})$. There were no significant differences in these parameters between G5 and G2, G3, G4; and no differences between each group.

Asphyxia at delivery was seen in $12.3 \%$ of total cases, and the rate was significantly higher in G5 $(21.8 \%$ vs $\mathrm{G} 2, \mathrm{G} 3, \mathrm{P}<0.01$; vs $\mathrm{G} 4, \mathrm{P}=\mathrm{NS})$ and $\mathrm{G} 4$ (19.5\% vs G2 and G3, $\mathrm{P}<0.01)$ (Table 3 ).
3) Chronological age ( $C A)$, bone age $(B A)$ and ratio of $B A / C A$ in 5 groups at registration

Although, the mean chronological age of G1 at registration was $9.5 \pm 0.02 \mathrm{yr}(\mathrm{n}=23,109), \mathrm{G} 5$ was significantly younger $(8.7 \pm 0.4 \mathrm{yr}, \mathrm{n}=139)$ than $\mathrm{G} 2, \mathrm{G} 3$ and G4 $(\mathrm{P}<0.005)($ Table $4 \mathrm{a})$. Mean bone age in G5 $(4.8 \pm 0.33 \mathrm{yr}, \mathrm{n}=120)$ was also significantly younger than G2, G3 and G4 [the totals of G2, G3 and G4 were $6.9 \pm 0.02 \mathrm{yr}, \mathrm{n}=19,955 ; 7.4 \pm 0.09 \mathrm{yr}, \mathrm{n}=1,711$ and $7.4 \pm 0.20 \mathrm{yr}, \mathrm{n}=339$, respectively] $(\mathrm{P}<0.001)$ (Table $4 b)$.

Further, the ratio of $\mathrm{BA} / \mathrm{CA}$ in $\mathrm{G} 5(0.52 \pm 0.02$,

a) Birth weight

Table 2. Birth weight (a), birth length (b) and gestational age (c) in the five groups

\begin{tabular}{|c|c|c|c|c|c|c|c|c|c|}
\hline & \multicolumn{3}{|c|}{ total } & \multicolumn{3}{|c|}{ boy } & \multicolumn{3}{|c|}{ girl } \\
\hline & Mean (g) & SEM & No. & Mean (g) & SEM & No. & Mean $(\mathrm{g})$ & SEM & No. \\
\hline G1 & $2,890.2$ & 3.3 & 22,615 & $2,913.3$ & 4.0 & 15,487 & $2,840.1$ & 5.7 & 7,128 \\
\hline G2 & $2,886.8$ & 3.4 & 20,188 & $2,910.2$ & 4.2 & 13,758 & $2,836.5$ & 5.9 & 6,430 \\
\hline G3 & $2,915.0$ & 12.0 & 1,828 & $2,937.2$ & 14.8 & 1,295 & $2,860.9$ & 20.2 & 533 \\
\hline G4 & $2,935.9$ & 25.4 & 385 & $2,944.2$ & 28.1 & 294 & $2,909.1$ & 57.1 & 91 \\
\hline G5 & $2,962.7$ & 53.0 & 135 & $2,978.4$ & 61.6 & 81 & $2,939.3$ & 94.9 & 54 \\
\hline
\end{tabular}

b) Birth length

\begin{tabular}{|c|c|c|c|c|c|c|c|c|c|}
\hline & \multicolumn{3}{|c|}{ total } & \multicolumn{3}{|c|}{ boy } & \multicolumn{3}{|c|}{ girl } \\
\hline & Mean $(\mathrm{cm})$ & SEM & No. & Mean $(\mathrm{cm})$ & SEM & No. & Mean $(\mathrm{cm})$ & SEM & No. \\
\hline G1 & 47.9 & 0.04 & 6,594 & 48.1 & 0.04 & 4,431 & 47.6 & 0.07 & 2,163 \\
\hline G2 & 47.9 & 0.04 & 6,214 & 48.1 & 0.05 & 4,158 & 47.6 & 0.07 & 2,056 \\
\hline G3 & 48.0 & 0.15 & 324 & 48.3 & 0.18 & 237 & 47.4 & 0.26 & 87 \\
\hline G4 & 48.4 & 0.59 & 32 & 49.0 & 0.55 & 22 & 47.0 & 1.35 & 10 \\
\hline G5 & 46.9 & 1.26 & 11 & 46.5 & 2.56 & 5 & 47.3 & 0.87 & 6 \\
\hline
\end{tabular}

c) Gestational age

\begin{tabular}{|c|c|c|c|c|c|c|c|c|c|}
\hline & \multicolumn{3}{|c|}{ total } & \multicolumn{3}{|c|}{ boy } & \multicolumn{3}{|c|}{ girl } \\
\hline & week & SEM & No. & week & SEM & No. & week & SEM & No. \\
\hline G1 & 39.1 & 0.01 & 22,110 & 39.1 & 0.02 & 15,117 & 39.2 & 0.02 & 6,993 \\
\hline $\mathrm{G} 2$ & 39.1 & 0.01 & 19,791 & 39.1 & 0.02 & 13,472 & 39.2 & 0.02 & 6,319 \\
\hline G3 & 39.1 & 0.06 & 1,756 & 39.1 & 0.07 & 1,241 & 39.2 & 0.10 & 515 \\
\hline G4 & 39.2 & 0.11 & 357 & 39.1 & 0.12 & 271 & 39.3 & 0.28 & 86 \\
\hline G5 & 38.9 & 0.24 & 129 & 38.9 & 0.30 & 76 & 38.9 & 0.40 & 53 \\
\hline
\end{tabular}

Table 3. Asphyxia at delivery in the five groups

\begin{tabular}{|c|c|c|c|c|c|c|c|c|c|c|c|c|c|c|c|}
\hline & \multicolumn{5}{|c|}{ total } & \multicolumn{5}{|c|}{ boy } & \multicolumn{5}{|c|}{ girl } \\
\hline & \multicolumn{2}{|c|}{ Asphyxia } & \multirow{2}{*}{ unknown } & \multirow{2}{*}{ sum } & \multirow{2}{*}{$\begin{array}{c}\text { rate of } \\
\text { Asphyxia }\end{array}$} & \multicolumn{2}{|c|}{ Asphyxia } & \multirow{2}{*}{ unknown } & \multirow{2}{*}{ sum } & \multirow{2}{*}{$\begin{array}{c}\text { rate of } \\
\text { Asphyxia }\end{array}$} & \multicolumn{2}{|c|}{ Asphyxia } & \multirow{2}{*}{ unknown } & \multirow{2}{*}{ sum } & \multirow{2}{*}{$\begin{array}{c}\text { rate of } \\
\text { Asphyxia }\end{array}$} \\
\hline & $(+)$ & $(-)$ & & & & $(+)$ & $(-)$ & & & & $(+)$ & $(-)$ & & & \\
\hline G1 & 2,654 & 18,405 & 592 & 21,651 & $12.3 \%$ & 1,844 & 12,521 & 423 & 14,788 & $12.5 \%$ & 810 & 5,884 & 169 & 6,863 & $11.8 \%$ \\
\hline G2 & 2,343 & 16,732 & 507 & 19,582 & $12.0 \%$ & 1,613 & 11,361 & 357 & 13,331 & $12.1 \%$ & 730 & 5,371 & 150 & 6,251 & $11.7 \%$ \\
\hline G3 & 227 & 1,321 & 65 & 1,613 & $14.1 \%$ & 166 & 922 & 53 & 1,141 & $14.5 \%$ & 61 & 399 & 12 & 472 & $12.9 \%$ \\
\hline G4 & 57 & 222 & 14 & 293 & $19.5 \%$ & 45 & 156 & 10 & 211 & $21.3 \%$ & 12 & 66 & 4 & 82 & $14.6 \%$ \\
\hline G5 & 22 & 74 & 5 & 101 & $21.8 \%$ & 15 & 40 & 2 & 57 & $26.3 \%$ & 7 & 34 & 3 & 44 & $15.9 \%$ \\
\hline
\end{tabular}


$\mathrm{n}=120$ ) was significantly lower than $\mathrm{G} 2, \mathrm{G} 3$ and $\mathrm{G} 4$ $(\mathrm{P}<0.001)$. The value of $\mathrm{G} 4(0.69 \pm 0.01, \mathrm{n}=339)$ was also significantly lower than G2 $(0.72 \pm 0.001$, $\mathrm{n}=19,954)(\mathrm{P}<0.01)$ and $\mathrm{G} 3(0.71 \pm 0.005, \mathrm{n}=1,711)$ $(\mathrm{P}<0.05)$ (Table 4c).

Patients with severe GH deficiency (G4 + G5; all $\mathrm{GH}$ peaks to provocative stimuli were below $2 \mu \mathrm{g} / \mathrm{L}$ ) showed a significantly lower BA/CA ratio compared to G2 and G3, while the ratios of the latter two groups were not significantly different.

\section{4) Height, height $S D S$ and serum IGF-I SD score in the 5 groups just before hGH treatment}

As it was arbitrarily classified, pretreatment height $(103.0 \pm 2.0 \mathrm{~cm}, \mathrm{n}=139)$ and HtSDS $(-4.98 \pm 0.08$, $\mathrm{n}=139)$ in G5 were significantly lower than G2, G3 and $\mathrm{G} 4(\mathrm{P}<0.001)$ (Table 5a, 5b).

HtSDS in G3 was significantly lower than that in G2 $(\mathrm{P}<0.01)$, and HtSDS in patients with severe GH deficiency $(\mathrm{G} 4+\mathrm{G} 5)$ were significantly lower than that in $\mathrm{G} 2$ and $\mathrm{G} 3(\mathrm{P}<0.001)$.

Mean pretreatment serum IGF-I values (SDS) in G5
$(-2.38 \pm 0.48, \mathrm{n}=18)$ was significantly lower than in $\mathrm{G} 2$ and $\mathrm{G} 3(\mathrm{G} 2,-1.38 \pm 0.01, \mathrm{n}=9,982 ; \mathrm{G} 3,-1.64 \pm$ $0.06, \mathrm{n}=564)(\mathrm{P}<0.001$ and 0.05$)($ Table 6). There were no significant differences between the values in G4 and G5. The IGF-I SD score in G3 and patients with severe GH deficiency (G4 + G5) were significantly lower than that in $\mathrm{G} 2$ (both $\mathrm{P}<0.01$ ), but there was no difference in the values between the former two groups.

\section{5) Parental height in the 5 groups}

Parental height of each group was within the normal ranges and there were no differences among G2 to G5 groups (Table 7).

\section{6) Improvement of HtSDS, final height and final $H t S D S$ in the 5 groups after hGH treatment}

Improvement of HtSDS ( $\Delta \mathrm{HtSDS})$ by hGH treatment was the greatest in G5 $(+2.02 \pm 0.51, \mathrm{n}=16)$ [vs G2 $(+0.99 \pm 0.02, \mathrm{n}=1,482), \mathrm{G} 3(+0.97 \pm 0.08$, $\mathrm{n}=250)$ and $\mathrm{G} 4 \quad(+0.93 \pm 0.09, \mathrm{n}=80), \mathrm{P}<0.025]$.

Table 4. Chronological age (yr) (a), bone age (yr) (b) and ratio of bone age/chronological age (c) in the five groups at registration a) $\mathrm{CA}$

\begin{tabular}{|c|c|c|c|c|c|c|c|c|c|}
\hline & \multicolumn{3}{|c|}{ total } & \multicolumn{3}{|c|}{ boy } & \multicolumn{3}{|c|}{ girl } \\
\hline & Mean & SEM & No. & Mean & SEM & No. & Mean & SEM & No. \\
\hline G1 & 9.5 & 0.02 & 23,109 & 9.6 & 0.03 & 15,824 & 9.1 & 0.04 & 7,285 \\
\hline G2 & 9.4 & 0.02 & 20,600 & 9.5 & 0.03 & 14,033 & 9.1 & 0.04 & 6,567 \\
\hline G3 & 10.1 & 0.08 & 1,891 & 10.3 & 0.10 & 1,341 & 9.7 & 0.14 & 550 \\
\hline G4 & 10.6 & 0.17 & 398 & 10.8 & 0.20 & 306 & 9.8 & 0.35 & 92 \\
\hline G5 & 8.7 & 0.40 & 139 & 8.7 & 0.52 & 83 & 8.9 & 0.65 & 56 \\
\hline
\end{tabular}

b) $\mathrm{BA}$

\begin{tabular}{|c|c|c|c|c|c|c|c|c|c|}
\hline & \multicolumn{3}{|c|}{ total } & \multicolumn{3}{|c|}{ boy } & \multicolumn{3}{|c|}{ girl } \\
\hline & Mean & SEM & No. & Mean & SEM & No. & Mean & SEM & No. \\
\hline G1 & 7.0 & 0.02 & 22,186 & 7.0 & 0.03 & 15,182 & 7.0 & 0.04 & 7,004 \\
\hline $\mathrm{G} 2$ & 6.9 & 0.02 & 19,955 & 6.9 & 0.03 & 13,603 & 6.9 & 0.04 & 6,352 \\
\hline G3 & 7.4 & 0.09 & 1,711 & 7.4 & 0.11 & 1,207 & 7.3 & 0.16 & 504 \\
\hline G4 & 7.4 & 0.20 & 339 & 7.3 & 0.24 & 257 & 7.6 & 0.37 & 82 \\
\hline G5 & 4.8 & 0.33 & 120 & 4.5 & 0.43 & 69 & 5.1 & 0.51 & 51 \\
\hline
\end{tabular}

c) $\mathrm{BA} / \mathrm{CA}$

\begin{tabular}{|c|c|c|c|c|c|c|c|c|c|}
\hline & \multicolumn{3}{|c|}{ total } & \multicolumn{3}{|c|}{ boy } & \multicolumn{3}{|c|}{ girl } \\
\hline & Mean & SEM & No. & Mean & SEM & No. & Mean & SEM & No. \\
\hline G1 & 0.72 & 0.001 & 22,185 & 0.70 & 0.001 & 15,182 & 0.75 & 0.002 & 7,003 \\
\hline $\mathrm{G} 2$ & 0.72 & 0.001 & 19,954 & 0.70 & 0.001 & 13,603 & 0.75 & 0.002 & 6,351 \\
\hline G3 & 0.71 & 0.005 & 1,711 & 0.70 & 0.006 & 1,207 & 0.74 & 0.008 & 504 \\
\hline G4 & 0.69 & 0.011 & 339 & 0.67 & 0.013 & 257 & 0.75 & 0.020 & 82 \\
\hline G5 & 0.52 & 0.018 & 120 & 0.50 & 0.022 & 69 & 0.55 & 0.029 & 51 \\
\hline
\end{tabular}


Table 5. Pretreatment height (a) and height SDS (b) in the five groups just before hGH treatment

a) $\mathrm{Ht}$

\begin{tabular}{|c|c|c|c|c|c|c|c|c|c|}
\hline & \multicolumn{3}{|c|}{ total } & \multicolumn{3}{|c|}{ boy } & \multicolumn{3}{|c|}{ girl } \\
\hline & Mean $(\mathrm{cm})$ & SEM & No. & Mean $(\mathrm{cm})$ & SEM & No. & Mean $(\mathrm{cm})$ & SEM & No. \\
\hline G1 & 118.3 & 0.1 & 23,110 & 119.4 & 0.1 & 15,824 & 115.9 & 0.2 & 7,286 \\
\hline G2 & 118.1 & 0.1 & 20,601 & 119.2 & 0.1 & 14,033 & 115.9 & 0.2 & 6,568 \\
\hline G3 & 120.3 & 0.4 & 1,891 & 121.6 & 0.5 & 1,341 & 117.0 & 0.8 & 550 \\
\hline G4 & 123.2 & 0.9 & 398 & 124.3 & 1.0 & 306 & 119.2 & 1.8 & 92 \\
\hline G5 & 103.0 & 2.0 & 139 & 103.1 & 2.6 & 83 & 102.8 & 3.3 & 56 \\
\hline
\end{tabular}

b) HtSDS

\begin{tabular}{|c|c|c|c|c|c|c|c|c|c|}
\hline & \multicolumn{3}{|c|}{ total } & \multicolumn{3}{|c|}{ boy } & \multicolumn{3}{|c|}{ girl } \\
\hline & Mean & SEM & No. & Mean & SEM & No. & Mean & SEM & No. \\
\hline G1 & -2.74 & 0.01 & 23,110 & -2.68 & 0.01 & 15,824 & -2.87 & 0.01 & 7,286 \\
\hline $\mathrm{G} 2$ & -2.70 & 0.01 & 20,601 & -2.64 & 0.01 & 14,033 & -2.83 & 0.01 & 6,568 \\
\hline G3 & -2.93 & 0.02 & 1,891 & -2.85 & 0.03 & 1,341 & -3.11 & 0.04 & 550 \\
\hline G4 & -2.74 & 0.03 & 398 & -2.73 & 0.04 & 306 & -2.80 & 0.07 & 92 \\
\hline G5 & -4.98 & 0.08 & 139 & -4.87 & 0.10 & 83 & -5.14 & 0.13 & 56 \\
\hline
\end{tabular}

Table 6. Pretreatment IGF-I SD score in the five groups

\begin{tabular}{|c|c|c|c|c|c|c|c|c|c|}
\hline & \multicolumn{3}{|c|}{ total } & \multicolumn{3}{|c|}{ boy } & \multicolumn{3}{|c|}{ girl } \\
\hline & Mean & SEM & No. & Mean & SEM & No. & Mean & SEM & No. \\
\hline G1 & -1.39 & 0.01 & 10,642 & -1.38 & 0.01 & 7,253 & -1.43 & 0.02 & 3,389 \\
\hline $\mathrm{G} 2$ & -1.38 & 0.01 & 9,982 & -1.36 & 0.02 & 6,776 & -1.41 & 0.02 & 3,206 \\
\hline G3 & -1.64 & 0.06 & 564 & -1.60 & 0.08 & 415 & -1.73 & 0.12 & 149 \\
\hline G4 & -1.83 & 0.29 & 60 & -1.73 & 0.39 & 41 & -2.06 & 0.34 & 19 \\
\hline G5 & -2.38 & 0.48 & 18 & -2.58 & 0.78 & 8 & -2.22 & 0.58 & 10 \\
\hline
\end{tabular}

Father

Table 7. Parental height in the five groups

\begin{tabular}{|c|c|c|c|c|c|c|c|c|c|}
\hline & \multicolumn{3}{|c|}{ total } & \multicolumn{3}{|c|}{ boy } & \multicolumn{3}{|c|}{ girl } \\
\hline & Mean $(\mathrm{cm})$ & SEM & No. & Mean $(\mathrm{cm})$ & SEM & No. & Mean $(\mathrm{cm})$ & SEM & No. \\
\hline G1 & 165.4 & 0.05 & 22,464 & 165.4 & 0.06 & 15,382 & 165.5 & 0.07 & 7,082 \\
\hline G2 & 165.4 & 0.05 & 20,098 & 165.3 & 0.06 & 13,701 & 165.5 & 0.07 & 6,397 \\
\hline G3 & 165.5 & 0.18 & 1,785 & 165.6 & 0.20 & 1,261 & 165.4 & 0.38 & 524 \\
\hline G4 & 167.2 & 0.30 & 374 & 166.9 & 0.33 & 287 & 168.0 & 0.67 & 87 \\
\hline G5 & 166.0 & 0.56 & 131 & 165.8 & 0.73 & 77 & 166.5 & 0.87 & 54 \\
\hline
\end{tabular}

Mother

\begin{tabular}{|c|c|c|c|c|c|c|c|c|c|}
\hline & \multicolumn{3}{|c|}{ total } & \multicolumn{3}{|c|}{ boy } & \multicolumn{3}{|c|}{ girl } \\
\hline & Mean $(\mathrm{cm})$ & SEM & No. & Mean $(\mathrm{cm})$ & SEM & No. & Mean $(\mathrm{cm})$ & SEM & No. \\
\hline G1 & 152.3 & 0.05 & 22,512 & 152.2 & 0.06 & 15,413 & 152.4 & 0.08 & 7,099 \\
\hline $\mathrm{G} 2$ & 152.2 & 0.05 & 20,141 & 152.2 & 0.06 & 13,729 & 152.4 & 0.08 & 6,412 \\
\hline G3 & 152.6 & 0.15 & 1,788 & 152.6 & 0.15 & 1,262 & 152.4 & 0.35 & 526 \\
\hline G4 & 153.8 & 0.25 & 376 & 153.8 & 0.30 & 289 & 154.0 & 0.46 & 87 \\
\hline G5 & 154.3 & 0.46 & 132 & 154.4 & 0.62 & 78 & 154.1 & 0.70 & 54 \\
\hline
\end{tabular}


Table 8. Improvement of HtSDS ( $\triangle \mathrm{HtSDS}$ ) (a), final height (b) and final HtSDS (c) after hGH treatment in the five groups a) $\Delta \mathrm{HtSDS}$

\begin{tabular}{|c|c|c|c|c|c|c|c|c|c|}
\hline & \multicolumn{3}{|c|}{ total } & \multicolumn{3}{|c|}{ boy } & \multicolumn{3}{|c|}{ girl } \\
\hline & Mean & SEM & No. & Mean & SEM & No. & Mean & SEM & No. \\
\hline G1 & 0.99 & 0.02 & 1,839 & 1.03 & 0.03 & 1,146 & 0.93 & 0.04 & 693 \\
\hline $\mathrm{G} 2$ & 0.99 & 0.02 & 1,482 & 1.02 & 0.03 & 894 & 0.93 & 0.04 & 588 \\
\hline G3 & 0.97 & 0.08 & 250 & 1.00 & 0.10 & 168 & 0.91 & 0.10 & 82 \\
\hline G4 & 0.93 & 0.09 & 80 & 0.97 & 0.09 & 68 & 0.73 & 0.27 & 12 \\
\hline G5 & 2.02 & 0.51 & 16 & 2.35 & 0.78 & 9 & 1.60 & 0.55 & 7 \\
\hline
\end{tabular}

b) Final $\mathrm{Ht}$

\begin{tabular}{|c|c|c|c|c|c|c|c|c|c|}
\hline & \multicolumn{3}{|c|}{ total } & \multicolumn{3}{|c|}{ boy } & \multicolumn{3}{|c|}{ girl } \\
\hline & Mean $(\mathrm{cm})$ & SEM & No. & Mean $(\mathrm{cm})$ & SEM & No. & Mean $(\mathrm{cm})$ & SEM & No. \\
\hline G1 & 155.7 & 0.2 & 1,841 & 160.6 & 0.2 & 1,148 & 147.5 & 0.2 & 693 \\
\hline G2 & 155.5 & 0.2 & 1,483 & 160.6 & 0.2 & 895 & 147.8 & 0.2 & 588 \\
\hline G3 & 155.8 & 0.6 & 250 & 160.4 & 0.6 & 168 & 146.3 & 0.6 & 82 \\
\hline G4 & 159.7 & 0.7 & 80 & 161.7 & 0.5 & 68 & 148.1 & 1.0 & 12 \\
\hline G5 & 149.4 & 3.2 & 17 & 154.8 & 4.5 & 10 & 141.6 & 2.3 & 7 \\
\hline
\end{tabular}

c) Final HtSDS

\begin{tabular}{|c|c|c|c|c|c|c|c|c|c|}
\hline & \multicolumn{3}{|c|}{ total } & \multicolumn{3}{|c|}{ boy } & \multicolumn{3}{|c|}{ girl } \\
\hline & Mean & SEM & No. & Mean & SEM & No. & Mean & SEM & No. \\
\hline G1 & -1.87 & 0.03 & 1,841 & -1.75 & 0.03 & 1,148 & -2.06 & 0.04 & 693 \\
\hline G2 & -1.85 & 0.03 & 1,483 & -1.74 & 0.03 & 895 & -2.02 & 0.04 & 588 \\
\hline G3 & -1.95 & 0.08 & 250 & -1.79 & 0.11 & 168 & -2.30 & 0.11 & 82 \\
\hline G4 & -1.61 & 0.09 & 80 & -1.55 & 0.10 & 68 & -1.96 & 0.21 & 12 \\
\hline G5 & -2.97 & 0.51 & 17 & -2.80 & 0.81 & 10 & -3.22 & 0.44 & 7 \\
\hline
\end{tabular}

However, there were no significant differences among the other groups (G2 to G4) (Table 8a).

Although G5 had the best $\Delta \mathrm{HtSDS}$, the final height (boy, $154.8 \pm 4.5 \mathrm{~cm}$; girl, $141.6 \pm 2.3 \mathrm{~cm}$ ) and the final height SDS (total, $-2.97 \pm 0.51$; boy, $-2.80 \pm 0.81$, $\mathrm{n}=10$; girl, $-3.22 \pm 0.44, \mathrm{n}=7$ ) of G5 were the lowest among the four $(\mathrm{G} 2$ to $\mathrm{G} 5)$ groups $(\mathrm{P}<0.025)$ (Table $8 b, 8 c)$.

\section{Discussion}

The ratio of very severe short stature with severe GH deficiency (G5) was $139(0.6 \%)$ out of 23,110 patients with IGHD. In G5, there were no significant differences in birth length and gestational age between G2, G3, and G4. However, birth weight in G5 was slightly greater than those of the other groups and asphyxia at delivery was more frequent in G5 and G4, than in G2 and G3.

These results indicate that patients with very severe
GHD (G4 + G5) have greater risk of asphyxia at delivery compared to other groups despite normal intrauterine growth.

Parental height in G5 was similar to G2 to G4, but their chronological age (CA), bone age (BA) and BA/ $\mathrm{CA}$ ratio at registration were significantly lower than these groups. As it was arbitrarily defined, pretreatment height and HtSDS in G5 were significantly lower than G2 to G4. IGF-I SD score in G5 was lower than G2 and G3, although there were no statistical differences between G5 and G4.

These results indicate that growth failure in G5 is not based mainly on familial origin, but is dependent upon their own GH deficiency. Such severe short stature might tend to make their parents to consult specialists earlier for growth disorders. It is reported that patients with severe GHD tend to have been diagnosed at a younger age $[10,11]$.

Although it did not reach statistical significance, mean IGF-I SD score in G5 was lower than that of G4. In addition, mean $\mathrm{BA} / \mathrm{CA}$ ratio in $\mathrm{G} 5$ was significantly 
lower than that of G4. Therefore, it seems that GH secretory capacity in G5 is more severely decreased than in G4. In patients with severe GHD (G4+G5), pretreatment HtSDS and BA/CA ratio were both lower than those in G3. Accordingly, severe GHD is highly probable when all peak GH values to provocative stimuli are below $2 \mu \mathrm{g} / \mathrm{L}$. Related to this, peak GH value is defined as below $3 \mu \mathrm{g} / \mathrm{L}$ after ITT (insulin tolerance test) for the diagnosis of profound adult GHD [12]. It is assumed that the etiology of G5 might be different from that of G2, G3 and G4.

Clinical and endocrine data might reveal a spectrum of difference according to the severity of GH deficiency, since HtSDS and IGF-I SD scores in G3 were both lower than those in $\mathrm{G} 2$.

After the hGH treatment, the final height and final height SDS in G5 remained the lowest. Nevertheless, the $\Delta \mathrm{HtSDS}$ value in $\mathrm{G} 5$ was the greatest among the four (G2 to G5) groups. From these data, early treat- ment starting before significant height deficit develops is desirable in G5 to achieve better final height [13], although hGH treatment in this group was started earlier than the other groups (G2 to G4).

In conclusion, the percentage of severe short stature with severe GH deficiency (G5) is only $0.6 \%$ of IGHD. Growth failure in G5 seems to occur after birth, and the etiology of growth failure might be different from that of other patients with IGHD. Further study is necessary to elucidate the precise incidence of the abnormalities of GH gene or GH related genes in G5. Early diagnosis and $\mathrm{hGH}$ treatment are needed to achieve better final height.

\section{Acknowledgments}

We thank Steve Sugino for his assistance of preparation with this manuscript.

\section{References}

1. Attie KM (2000) Genetic studies in idiopathic short stature. Curr Opin Pediatr 12: 400-404.

2. Dattani MT, Martinez-Barbera JP, Thomas PQ, Brickman JM, Gupta R, Martensson IL, Toresson H, Fox M, Wales JK, Hindmarsh PC, Krauss S, Beddington RS, Robinson IC (1998) Mutations in the homeobox genes HESX1/Hesx1 associated with septo-optic dysplasia in human and mouse. Nat Genet 19: 125-133.

3. Abuzzahab MJ, Schneider A, Goddard A, Grigorescu F, Lautier C, Keller E, Kiess W, Klammt J, Kratzsch J, Osgood D, Pfaffle R, Raile K, Seidel B, Smith RJ, Chernausek SD; Intrauterine Growth Retardation (IUGR) Study Group (2003) IGF-I receptor mutations resulting in intrauterine and postnatal growth retardation. $N$ Engl J Med 349: 2211-2222.

4. Wagner JK, Eble A, Hindmarsh PC, Mullis PE (1998) Prevalence of human GH-1 gene alterations in patients with isolated growth hormone deficiency. Pediatr Res 43: 105-110.

5. Vimpani GV, Vimpani AF, Lidgard GP, Cameron EHD, Farquhar JW (1977) Prevalence of severe growth deficiency. Br Med J 2: 427-430.

6. Lacey KA, Parkin JM (1974) Causes of short stature: a community study of children in Newcastle upon Tyne. Lancet 1: 42-45.

7. Rona RJ, Tanner JM (1977) Aetiology of idiopathic growth hormone deficiency in England and Wales. Arch Dis Child 52: 197-208.

8. Lindsay R, Feldkamp M, Harris D, Robertson J, Rallison
M (1994) Utah growth study: growth standards and the prevalence of growth hormone deficiency. $J$ Pediatr 125: 29-35.

9. Fujieda K, Shimatsu A, Hanew K, Tanaka T, Yokoya S, Miyaji Y, Hizuka N, Hasegawa Y, Tachibana K, Ohyama K, Seino Y, Katou Y, Nishi Y, Kohno H, Irie M (1996) Clinical evaluation of serum IGF-I, IGF-II and IGFBP-3 measured by IRMA kits in childhood. Clin Endocrinol (Tokyo) 44: 1229-1239.

10. Tanaka T, Takano K, Hanew K, Nishi Y, Fujieda K, Tachibana K, Yokoya S, Igarashi Y, Hirano T (1996) Spontaneous growth in growth hormone-treated short children. Endocr J 43 (Suppl): S135-S136.

11. Attanasio AF, Howell S, Bates PC, Blum WF, Frewer P, Quigley C, Shalet SM (2002) Confirmation of severe $\mathrm{GH}$ deficiency after final height in patients diagnosed as GH deficient during childhood. Clin Endocrinol (Oxf) 56: 503-507.

12. Thorner MO, Bengtsson B-A, Ho KY, AlbertssonWikland K, Christiansen JS, Faglia G, Irie M, Isaksson O, Jorgensen JO, Ranke MB, Rosenfeld R, Schalet S, Takano K, Van der Veen EA, Weissberger A (1995) The diagnosis of growth hormone deficiency in adults. J Clin Endocrinol Metab 80: 3097-3098.

13. Rikken B, Massa GG, Wit JM, the Dutch Growth Hormone Working Group (1995) Final height in a large cohort of Dutch patients with growth hormone deficiency treated with growth hormone. Horm Res 43: 135-137. 